ESJ Humanities

\title{
Stuck in Slums: A Case Study of Slums in Islamabad, Pakistan
}

\author{
Persis Samuel \\ School of International and Public Affairs \\ Shanghai Jiao Tong University, China \\ Muhammad Shemyal Nisar \\ Department of Electronic Engineering \\ Shanghai Jiao Tong University, China
}

Doi: $10.19044 /$ esj.2021.v17n2p56

Submitted: 04 December 2020

Accepted: 11 January 2021

Published: 31 January 2021

\author{
Copyright 2021 Author(s) \\ Under Creative Commons BY-NC-ND \\ 4.0 OPEN ACCESS
}

Cite As:

Samuel P. \& Nisar S.M. (2021). Stuck in Slums: A Case Study of Slums in Islamabad, Pakistan. European Scientific Journal, ESJ, 17(2), 56.

https://doi.org/10.19044/esj.2021.v17n2p56

\begin{abstract}
This paper focuses on finding answers to the reasons why people keep living in the slums and why they cannot get out of their precarious conditions. This paper looks into different reasons for people being stuck in slums from a religious perspective. Reasons for different religious groups being stuck in slums are not explored fully in the literature. The analysis draws on qualitative research with a sample of $53 \mathrm{semi}$-structured interviews conducted in 8 katchi abadis in Islamabad, Pakistan. The study shows that slums are nonhomogenous entities and are regarded as a living organism that provide safety, security, and a sense of belonging to some of the residents. The results revealed that both Christian and Muslim slum residents had different reasons for living in slums. There were not only inter-religious differences in the choice of living but intra religious differences had also been found. In the process, the paper highlights that most Christians lived in slums by choice due to strong social capital, with an exception of a few. On the other hand, Muslim slum residents lived in poverty which was a major reason most of the slum dwellers are stuck in slums. Policymakers should meet the needs of the people before implementing any policies. This is because relocation policies can bring misery to some of the slum dwellers. Finally, the paper demonstrated that slums play a pivotal role in the lives of the slum dwellers in keeping them
\end{abstract}


stuck in that place.

Keywords: Slum heterogeneity, social capital, social and environmental reasons, place attachment, poverty

\section{Introduction}

Slum formation is not a new phenomenon; they have existed for decades and have been studied for a long time. Today, more than half of the world's population lives in slums. These slums harbor most of the marginalized urban population. According to Osmani and Ergen (2019), slums are a negative product of urbanization. The dwellers residing in these slums are from the marginalized stratum of the society facing myriad challenges. There is a wide literature which discusses and targets those residing in decrepit housing units, where poverty and hunger prevail with no facilities and lack of human capital (Agarwal \& Taneja, 2005; Engstrom et al., 2019; Marx et al., 2013; Salon \& Gulyani, 2010). The slum dwellers spend all their lives in poor living conditions (Engstrom et al., 2015; Gulyani \& Bassett, 2010). However, a rich body of micro literature has shed light on why people live in slums. The reasons include low socioeconomic status, poor service provisions, and marginalization of slum residents (Auyero, 1999; Nath, 2009; Omole, 2010; Sanderson, 2012). On the other hand, Bird et al. (2018) stated that despite poor conditions in slums, the slum residents face far better conditions than rural areas.

On the other end of the spectrum, macro studies examine global and national trends of urban poverty, weak governance, poor working conditions, and poor quality of life (El-Shorbagy \& El-Shafie, 2014; Glaeser, 2014; Lucci et al., 2017; Sartori et al., n.d.; Turok \& Borel-Saladin, 2016). All these factors, as discussed in the literature, tend to keep people stuck in slums. Despite poor living conditions, the number of residents are growing and a significant number of people continue to live in slums. It imposes a big question, which calls for an improvement in the living conditions of people through better policy design with the understanding of the commonalities and differences across slums within and between different groups residing in slums. These groups can include both religious and ethnic groups.

To understand the persistence and growing number of slum dwellers in these dwellings, this research investigates the following questions: Why are people stuck (live) in slums for a long time? And why can't they get out of slums? Thus, the studies discussed above clearly mentioned that slum dwellers spend their lives in great misery and poor conditions but continue to live there. Different factors for keeping people in slums have been discussed in the literature, but these studies fail to give a holistic picture of the situation of the slum dwellers. The literature fails to shed more light on the differences among 
different religious groups but instead treats slums homogenously. Attention must be turned to how interventions shape the behavior of different people groups living in such places. Given the vulnerabilities that slum dwellers face, it is necessary to investigate along religious lines to know the reasons why the slum dwellers are living there and cannot get out of the precarious conditions. Therefore, this research found out some of the reasons people still continue living in slums from two religious' groups, Muslims and Christians. The novelty of this study lies in bringing a new perspective that all slum dwellers do not have the same reasons for living in slums. Even among the same religious groups, people tend to have different reasons for staying. Our results here elucidate that all slum households are not poor. Second, slum residents have heterogeneous living conditions, depending on their socio-economic conditions and other factors which contribute to keeping them in slums.

The study took place in 8 katchi abadis in Islamabad, Pakistan. Since the study was exploratory in nature, it uses a qualitative method by conducting 53 interviews in katchi abadis using a snowballing technique. Firstly, the study found out that slums are non-homogenous entities. Secondly, the study contributes to the existing literature by addressing the gaps in the literature, showing that different religious groups have different reasons for staying in slums. Thirdly, the study found that within religious groups, people have different reasons for staying in slums. Fourthly, the reason for staying also depends on the function of the slums which plays an important role in keeping people stuck there. Lastly, this study showed gaps in policy formation in slums which leads to the suffering of the people of katchi abadis.

The paper is structured as follows. The literature review is discussed in section 2; methodology in section 3; and ethical considerations in section 4. Section 5 shows the results of the study, section 6 focuses on the discussion part, and section 7 shows the conclusion.

\section{Literature Review}

\subsection{Reasons for Being Stuck in Slums}

Earlier studies shed light on the reasons that keep people stuck in slums. Although housing is a basic human right, yet millions of people do not have a roof over their heads. The provision of affordable housing has become a huge challenge for national authorities. The literature on affordable housing is divided into two major themes. Some studies talk about the lack of government policies and others shed light on the lack of interventions along with policies for unaffordable housing that keep people in slums. Addo (2014), Cerezo (2003), and Shams et al. (2014) noted the failure of government together with political bias in providing affordable housing to the poor strata of the society. More and more people end up in slums and informal settlements as low-income housing projects are taken away by the middle to high-income 
groups. Baker (2007), Brueckner and Lall (2014), Gandhi (2012), and Rashid (2009) argued that housing conditions have not been improved for the poor due to policy implementation failure resulting in increasing contortion in the land and housing markets. Thus, this leads to failure in resolving the problems of affordable housing and slums, thereby increasing the vulnerability of the poor. On the other hand, Adabde and Chan (2014) acknowledged the fact that attention has been paid by the policymakers to interventions for sustainability in attaining affordable housing, but the potential and efficient interventions are being overlooked. Their study suggested some potential critical success factors (CSFs) for sustainable housing for the poor. Lucci et al. also suggested that interventions like land-use planning along with infrastructure development and city upgrading needs to be looked into along with twin-track approach as the housing market fails to accommodate the poor (Bah et al., 2018; Lucci et al., 2015). One response to the reason for people being stuck in informal settlements has gained significant attention. The rationale behind this comes from the idea that the soaring property prices and price of dwelling household income are not syncing. It has been argued that high prices have made owning a home a dream for the poor (Adabre \& Chan, 2014; Gandhi, 2012). In this case, only 5-6\% of the population in Mumbai can own a house in Mumbai (Gandhi, 2012). Thus, the notion of affordable housing needs exigent policy strengthening for housing markets to bring about a synchronizing between household income and house prices.

According to the Human capital theory, taking part in getting an education is regarded as an investment in human capital because of the expected returns later in life (Becker, 1965). So, it can be argued that as the level of education increases in a society, the productivity of its people also increases with that knowledge. There is a consensus in the literature that shows that slum dwellers, who are less educated, face severing human capital constraints as low incomes and informal jobs are taken up by this segment of the society due to the lack of education and employment training (Hossain, 2007; Zulu et al., 2011). This low income of the household leads to poverty and vulnerability of slum dwellers. It is hard for the poor to find jobs and even harder if the job lacks opportunities for advancement, offers low wages and limited employment security, social protection, and working conditions that present safety and health risk. Evidence from Peru shows that jobs generally require hard labour which leads to low productivity. Poor health is also a major factor that prevents people with low education from working, thereby lowering their income (Murrugarra \& Valdivia, 1999; Östergren, 2018).

Ethnic discrimination and religious discrimination are the two most important reasons which the literature suggests for people being stuck in slums. While a plethora of evidence is available regarding racial discrimination in employment and its implications for the racial group's life 
chances (Avery et al., 2008; Kain, 1968; Pager \& Shepherd, 2008), the subject has been studied by Davis (2004) with a specific interest of looking at the discrimination faced by dark-skinned slum dwellers from Rio De Janerio in securing employment for themselves. This phenomenon is not only prevalent in the developing world but has been reported in cities like Paris where Arabic sounding names and postcodes of areas where the Arab population lives are faced with discrimination when it comes to employment opportunities (Geary \& Graff, 2005). In Rio de Janeiro's favelas, the residents earned 10-47 percent less than those in the neighbourhoods who work in the same occupation with the same education, age, and gender characteristics (Pero et al., 2003). Prolonged unemployment and unsafe jobs offer no hope to the poor to get out of their situation and to escape poverty. The effect of such discrimination leads to a reduction in the life chances available to the slum dwellers who are then forced into the vicious cycle of poverty due to such discrimination. With the employment opportunities drying up, these people are forced to either seek to engage in self-employment as a means to feed themselves and their families or suffer from disease and hunger due to underpaid employment or complete lack of employment opportunities for them. They might also resort to illicit activities for which the slums are notoriously famous for. The second effect discrimination brings about a slum is that it forces a demographic change of a slum through the selective provision of social mobility to certain groups based on race and religion while restricting it for others.

Studies showed that not only the earning members but also their children do not get an education. Multiple interwoven factors (family background, school-related factors, low income of family, etc.) which leads to low education of children usually result to early dropouts (Chug, n.d.; Hasan \& Mohib, 2003; Sultana, 2019). Income and large family size are the factors that affect the educational achievements and the affordability of education among the poor. This is seen in Latin America and the Caribbean (Ferranti et al., 2004). Menon et al. (2013) discusses the barriers to parental involvement in early childhood education. On the other hand, Cameron (2009) acknowledges parents and children's involvement in valuing education, having high hopes for a good future, and considering education as a way of getting out of poverty, vulnerability, and poor living conditions. Nonetheless, the poor are unable to access relatively low-cost education due to the negligence of the government. According to J. Stokes (1962), the low level of income leads to poverty. Slum-dwellers may find themselves trapped in slums by having low income hindering their investment in human capital.

Social capital is also another factor responsible for keeping people in slums. Research on social capital sheds light on its importance on the economic wellbeing of individuals (Amirthalingam \& Lakshman, 2009; Chimhowu \& Hulme, 2006). The notion of social capital has been popularized 
through the works of Bourdieu (2018). Portes and Putnam argued that social capital is a product of relationships that a person has and the ability of the individual to utilize these relations for the improvement of his economic wellbeing (Portes, 1998; Robert, 1999). Apart from the economic benefits that an individual accrues from his social group, there have been many reports of psychological benefits that are derived by an individual from his social group. Individualism, although a much-celebrated trait in the contemporary world, has been found to have a negative correlation with happiness in a society (Lee et al., 2018). The benefits that a person accrues from kinship networks and social support networks include enhanced immunity to psychological disorders including schizophrenia, psychotic disorder, and bipolar disorder (Sweet et al., 2018). Voluminous literature, therefore, has shown the importance of social capital in the psychological well-being of an individual, so much so that these individuals desire to seek the social connectedness and social locatedness in their lives (Lee et al., 2018; Newman et al., 2018; Steel et al., 2018; Sweet et al., 2018).

Subsequently, the measurement of this social capital among slum dwellers is thus important to be addressed. Cohen says that social networks enable the provision of psychological resources as well as material resources that help people cope with stress and loneliness (Cohen, 2004). Coleman functionalizes this definition by arguing that social capital is determined through the function it plays. The social capital, thus for Coleman, is that entity that has some aspects of social structure, and it somehow facilitates the wellbeing of individuals socially located within that structure (Coleman, 1990).

In the context of this study, it is sufficient to consider social capital to consists of indicators of social networks (structural: bonding), social support, and the diversity of friendship indicators (Tran, 2015). Thus it aims to facilitate social exchange according to Karen networks of trust developed under conditions of risk and uncertainty (Cook, 2005). According to Larsen et al. (2004) bonding, social capital is composed of association and trust between neighborhoods. The number of resources accessible through one's personal network can be expressed and measured as individual social capital (Lin, 2001). Therefore, this study will not only focus on one form of social network. In light of the above-cited literature, it can be argued that the social capital that the slum dwellers accumulate with their co-habitants of the slum is a major contributor to the lack of the desire of these dwellers to move or be removed from the slum. Them being moved to a different place outside the slum, even if objectively a better place, has negative consequences for the accumulated social capital of these dwellers. Hence, they keep on residing in the same place over the years even if they are presented with better alternatives. They can, therefore, be said to be stuck in slums. 


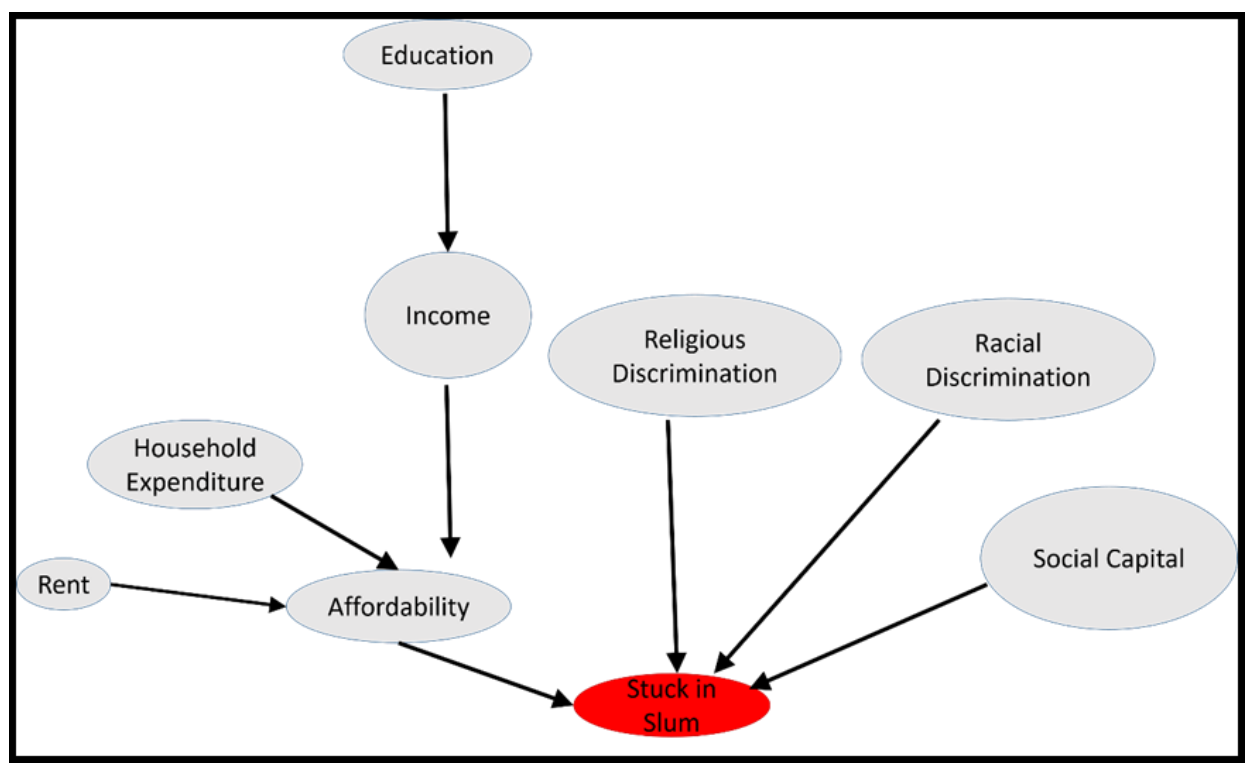

Figure 1. Factors for being stuck in slums

\section{Methodology}

\subsection{Selection of Study Area}

The study was carried out in Islamabad, the capital of Pakistan. The reason why Islamabad was chosen is that not many studies have been conducted there. There are more than 50 katchi abadis in Islamabad out of which 10 are regularized (Capital Development Authority - Planning Wing, 2019; Government of Pakistan, 2018). 8 regularized katchi abadis were chosen out of 10 because these katchi abadis are well demarcated by the government. People came to Islamabad as laborers at the time of the establishment of Islamabad in the early 1960s and have settled here since then.

Islamabad the capital territory in Pakistan is rapidly growing both economically and in terms of population. The city provides a good example of inequality. Here the number of gated communities is on the rise and the hands which build such communities have no place to go other than staying at the place they are allocated. This resulted to the kind of informal settlements (katchi abadis)/slums which are now sporadically spread around Islamabad. Built-in the 1960s, the city replaced Karachi as the capital of Pakistan. It is the only planned and designed city in the country. According to the Pakistan Bureau of Statistics, the population of the capital is around 2 million (Pakistan Bureau of Statistics, 2017). One of the issues of large cities, in general, and Islamabad in particular is katchi abadis (Temporary Housing Settlements/slums). Thus, the population of these slums exceeds 100,000 (Shah, 2016). 
Table 1. Names and locations of Katchi Abadis in Islamabad, Pakistan

\begin{tabular}{|rl|l|}
\hline Name of Katchi Abadis & Location \\
\hline 1. & Katchi Abadi G-7/1 (66 Quarters) & G-7/1 \\
\hline 2. & Katchi Abadi G-7/2 & G-7/2 \\
\hline 3. & Katchi Abadi G-7/3 (48 Quarters) & G-7/3-2 \\
\hline 4. & Katchi Abadi F-6/2 (100 Quarters) & F-6/2 \\
\hline 5. & Katchi Abadi F-7/4 (France Colony) & F-7/4 \\
\hline 6. & Katchi Abadi G-8/1(Hansa Colony) & G-8/1 \\
\hline 7. & Muslim Colony (Nor Pur Shahan) Bari Imam & \\
\hline 8. & Katchi Abadi Essa Nagri & $\mathrm{I}-9 / 1$ \\
\hline
\end{tabular}

\subsection{Data Collection}

Detailed qualitative data was collected. The data sources for this study were mostly primary data. However, along with primary data, secondary data was obtained to examine the situation in slums. The qualitative instruments of data collection were semi-structured interviews and observations. The secondary data was collected through news, media reports, books, and government documents to identify the reasons why some people live in the slums in Pakistan.

According to Oakley, a qualitative interview is a type of framework in which the practices and standards will not be only recorded but also achieved, challenged, and reinforced (Oakley, 1998). The in-depth interviews helped to gain an insight into what people think of their condition. It gave a thorough insight into the particular issues being raised in this research. The use of semistructured interviews gave a voice to those individuals who were being marginalized within the society. Furthermore, many feminist researchers have advocated this method which enables the participants to describe their lives and experiences in their own words, i.e., to 'tell it like it is'. Interviews are best suited for understanding people's perceptions and experiences. Thus, they enable us to get the thoughts, feelings, and viewpoints of the interviewees on their situation.

\subsection{Selection of Participants and Procedures}

During the selection of participants, snowballing sampling technique was used. Initially, one to two potential subjects in the population were contacted who were willing to make use of their personal contacts and referred us to other people with the potentials to contribute to the study. The basic principle behind choosing this sampling technique was to reach the target population with some references as it was difficult to reach out and find the target population on our own. Some slum dwellers may not be willing if directly contacted for an interview. This strategy best suited the research as it was used as a reference strategy and also helped in saving time. The same step 
was taken until the required sample size was achieved. This technique was deliberately designed to access the slum dwellers who know more about the people in their locale.

This technique helped in getting the views of all the religious groups in the slums regarding their conditions. Criteria like participants with different, religious, educational and income backgrounds were covered in this study. The overall picture of the situation was analyzed to find out why people continue to live in slums.

\subsection{Instruments of Data Collection \\ 3.4.1 Observations}

Firsthand information was collected through observation in the field. This helped in better understanding and capturing the context within which people interact with their habits, norms, practices, and rituals. It was also a great way of exploring and learning about the things that people were not willing to discuss in the interviews. These observations also included field notes, photographing, and tape-recordings.

\subsubsection{Semi-structured Interviews}

Semi-structured interview tools were useful for this study as it helped in exploring new ideas and topics in this field. As this research design does not restrict the interview to follow a formalized pattern of questions, it will allow the interviewees to narrate to the maximum limit of their knowledge. This method offers a balance between open-ended interviews and structures ethnographic surveys. 53 interviews were conducted in this study. Each interview lasted for 50-60 minutes to get a better understanding of the conditions and reasons which keep them in slums.

Before starting the main study, a pilot study was conducted by interviewing 15 slum dwellers at their dwellings. This helped in rectifying any errors in the final study. During the exercise, all the interviews were audiorecorded to ensure the correct use of the device. Observations included body language and the non-verbal response of the interviewees. All the interview questions were translated into the local language.

\subsection{Data Analysis}

Thematic analysis was used to analyze the data. The goal of thematic analysis was to become familiar with the data, generate codes, identify and explain themes, and use these themes to address the research issues. A detailed description of this method is explained in the table below. 
Table 2. Steps of thematic analysis (Maguire \& Delahunt, 2017; Nowell et al., 2017)

\begin{tabular}{|cl|l|}
\hline Phase & Description of the Process \\
\hline 1. $\quad$ Familiarization with data. & $\begin{array}{l}\text { Re-reading the transcripts, transcribing them and getting } \\
\text { familiarized with the data, noting the initial ideas }\end{array}$ \\
\hline $2 . \quad$ Generating initial codes & $\begin{array}{l}\text { Familiarization with data and generation of } \\
\text { the initial set of ideas leads to collating data to } \\
\text { relevant codes }\end{array}$ \\
\hline 3. Generation of themes & Organizing codes into potential themes \\
\hline 4. Reviewing of themes & $\begin{array}{l}\text { This step involves reviewing, modifying, and developing } \\
\text { the preliminary themes along with the data and the } \\
\text { codes to verify that the themes generated are } \\
\text { indeed accurate }\end{array}$ \\
\hline 5. Defining and naming \\
themes involved & $\begin{array}{l}\text { Final refinement of themes and the aim is to 'Identify the } \\
\text { 'essence' of what each theme is } \\
\text { about'. }\end{array}$ \\
\hline 6. Producing the report & $\begin{array}{l}\text { The final step of analyzing and producing a } \\
\text { coherent and engaging write up of the analysis } \\
\text { is carried out }\end{array}$ \\
\hline
\end{tabular}

\section{Ethical Considerations}

The ethical principles of social science research were seriously followed in this research. Before starting the interviews and recording activities, the purpose of the interviews and how the information will be used were explained to the participants. They were informed about the purpose and objectives of the research, what was expected of a research participant, including the time duration. Participation was voluntary based and anyone could withdraw at any time with no negative repercussions. The participants were briefed and were assured about the protection of their confidentiality. After the participants agreed, the relevant data was collected.

\section{Results}

The participants in the study were from two religious' groups. Muslims are a majority religious group in the country and Christians are a minority group. The details of the population demographics are given below in Table 1 showing that the average size of households is larger among Christian households but with a larger deviation in the data. The same holds for the number of children per household where children per Christian household are slightly larger compared to Muslims. The income of Muslim households is less as compared to the Christian residents. Less number of Muslim children go to school whereas the education of earning members of Muslim household members is also low. 
Table 3. Demographics of slum dwellers

\begin{tabular}{|c|c|c|c|}
\hline & & Christians & Muslims \\
\hline \multirow{2}{*}{$\begin{array}{l}\text { Household } \\
\text { size }\end{array}$} & Avg. & 8.1 & 7.7 \\
\hline & Std. & 4.6 & 4.4 \\
\hline \multirow{2}{*}{$\begin{array}{l}\text { Children per } \\
\text { household }\end{array}$} & Avg. & 4.1 & 3.8 \\
\hline & Std. & 2.9 & 2.4 \\
\hline \multirow{2}{*}{$\begin{array}{l}\text { Household } \\
\text { income }\end{array}$} & Avg. & 39,423 & 28,600 \\
\hline & Std. & $21,260.62$ & $16,778.56$ \\
\hline \multirow{2}{*}{$\begin{array}{l}\text { Children } \\
\text { schooling }\end{array}$} & In School & 71 & 65 \\
\hline & Out of School & 13 & 5 \\
\hline \multirow{5}{*}{$\begin{array}{l}\text { Education } \\
\text { level of } \\
\text { earning } \\
\text { members }\end{array}$} & Illiterate & 20 & 27 \\
\hline & Primary & 5 & 3 \\
\hline & $\begin{array}{l}\text { Below } 10^{\text {th }} \\
\text { Grade }\end{array}$ & 14 & 11 \\
\hline & $10^{\text {th }}$ Grade & 13 & 6 \\
\hline & Above & 2 & 2 \\
\hline
\end{tabular}

\subsection{Christian Participants}

participants:

1. Social capital (stay)

2. Social and environmental reasons (stay/leave)

\subsubsection{Social Capital}

Social capital is an important factor for keeping Christian residents in the slums. It can be approached from a different point of view and different forms. Structural social capital is based on three levels of social networks: bonding, bridging and linking. "Bonding" social capital is observed in the Christian community. It is connected to people who are similar in terms of their demographic characteristics, such as family members, neighbors, close friends, and work colleagues (Gittell \& Vidal, 1998). In addition, cognitive social capital (trust) operates and is very strong in the Christian community. Trust is an important factor in any social setting. Trust within the Christian community is very strong along with the duration of stay in slums which increases their Social capital. Most of the Christian residents explained the role of trust in keeping them in slums.

As the Christian residents explained:

"No, nobody will go. It's not only me, everybody will give you the same answer. We feel safe here. We even keep our gates open till midnight, if anyone has a problem and makes noise, we at once gather together for help. If we go to a new place people will be different there, we cannot trust a new person, we 
are living here for a long time."

"People trust each other within families, friends and neighbors also trust each other. We have been living here for a long time we know each other quite well."

The Christian residents further explained how trust has been developed over time and has helped them to keep it. The trustworthiness of other people has shaped their lives, and it has also helped them to work together to solve their problems.

"We will not go from here. We have all our relatives here; we know people around for a long time. We want the government to give us plots here."

"This church has been built by the people of this slum. 70-80 families helped in building it. We have a church committee but it's not financially strong to solve people's problems. It has just started, we are planning that next year on Christmas we will help the poor, widows and orphans."

"I will go with my neighbors; I won't go alone. As the neighbours will say I will do the same. In Ali Pur faresh, 55 households have been shifted but the rest are here. I will not go alone. I have my Christian community here; I will move if they move."

"I will not go alone. it's hard for me. If we go, we will not even have anyone to put us in the grave. We have all our friend's relatives and everybody is here. We cannot go alone. We will go with everyone."

Consequently, people greatly emphasized the importance of their Christian community and how it keeps them together. Therefore, they were not willing to leave the slums without their community members.

"We have our community and the people we know here. We live together. We take care of each other here. If we go somewhere else, these people will go far from us. Our neighbors come to us in every happiness and sorrow.".

"It's not possible if someone asks you to leave this place and you leave it, we have facilities here, we have our community here. If a person dies here there are a lot of people. 200-300 people are here."

People of the katchi abadis had some demands which they also expressed during the interview. If these demands are fulfilled, the lives of these katchi abadis would have been easier and better. 
"There is huge inequality regarding space in this slum; some have a lot of space others do not. We want the government to allot everybody the same size of plots. Our house is small but some people have big houses. In our street, there is a very big house."

\subsubsection{Social and Environmental Reasons (Stay/Leave)}

People who want to stay or leave the slums were few. Jobs, schools, and market places were factors related to keeping them in slums. On the other hand, poor environmental and social factors were mentioned as a source of dissatisfaction and leaving the slums. Having facilities in slums was another factor for keeping a few people stuck in slums.

"Our neighborhood has some problem. I want the environment of our slum to change and become good. Our children do not take drugs and drink but people do these kinds of things that affect our kids. If the environment is better than here, we will leave this place if the government provides us. Although we feel safe here, there are also guards here from other religious groups. These people take drugs and drink and they are having a bad influence on our children."

"This place is good as my husband's job is in the nearby market; so one has to think of everything before moving to a new place. I sometimes become fed up with this place but then we have to think of other things like our kid's schools are nearby; we can go to the market on foot. We think that if we leave this place, then we might have to face some problems. Then we think that this place is ok."

The slum dwellers expressed a desire to leave but still hope to stay if the place becomes clean, drug-free, and garbage-free. Phrases like "we do not like any other place than this" and "this place is best for us" showed how content the slum dwellers are to live there as they have facilities like schools, markets, and jobs nearby. Despite the concerns that the slums are dirty and they have addicts, a strong liking for the place is felt as the slum residents said:

"We do not like any other place than this place. We have all the facilities here. Kid's schools are near. But when I see garbage and dirt around, I want to shift. This place is best for us if it becomes clean, we would love to stay here."

"We want to stay because we have jobs here. If drugs are no more in slums, then we will not go." 


\subsection{Muslim Participants}

Two themes emerged for being stuck in slums for the Muslim participants

1. Place attachment (stay)

2. Poverty (leave)

\subsubsection{Place Attachment}

Few Muslim respondents wanted to stay and didn't want to leave slums due to place attachment. Emotional and social attachment both exists in slums. Place attachment described by Pretty et al. (2003) is the (individual and community) connections and bonds that people develop with places. Hummon (1992) described place attachment as 'emotional involvement with places' while Low (1992) considers it as 'an individual's cognitive or emotional connection to a particular setting or milieu'. A Muslim resident responded to this question in a very emotional manner. He had an emotional connection with the place where he stayed.

Q1. If you are given a choice to live somewhere else or the government provides you with affordable housing, will you leave this place? If yes, why will you leave? If no, why, what are the reasons for not leaving this place? Probe.

"Even if the government provides affordable housing I do not want to move from here. I do not want to leave this place. This place gives me peace of mind and heart. I want the government to give me a house here."

Besides emotional attachment, social attachment to the neighborhood was also reported in a few cases. The respondents showed attachment to people who lived in their neighborhood.

"We do not want to move; it will be very difficult to move out of this place because we have been living here for a long time. We were born here, we grew up at this place; it won't be adjustable for us to go somewhere else."

Another resident said:

"We will not leave this place, we have spent all our lives here, we are living here and cannot leave this place. We do not want to leave and live without our neighbors."

However, it has been observed that besides emotional attachment, people felt attached to their neighborhood. Without a doubt, when these two components of place attachment generally come together, they become a general affective feeling toward the place of residence based on emotional and 
social dimension.

\subsubsection{Poverty (Leave)}

Fear of being demolished, lack of facilities, ethnic segregation, garbage, and longing to live within one's own community were the factors that contribute to them leaving the slums. Despite all these issues, people were unable to get out of the slums due to poverty. The residents lived in constant terror of being demolished. Upon asking would you like to move from here, the Muslim respondents responded.

"Yes, we will leave if the government provides us a house, it will be ours, we will build it according to our needs. Yesterday, CDA came and they demolished walls here, I will go alone even if I have to go alone."

"If the place is good, I will leave this place. We are living here because we do not have a choice. There are no facilities here and most of the people here are Kashmiri and we do not have good terms with them. There are 6 to 7 halkas here; every sector has people of the same ethnicity."

The slum dwellers had a strong will to leave the slums. This reason includes not having basic facilities, less space, money for housing schemes, and lack of faith in the government for getting houses for which the government has promised.

"I will definitely leave this place because we do not have facilities here. Electricity is given to a few houses here only. Those who do not have one can go to hell-this is what the ones with electricity think. They have the right to supply electricity to whom they want to."

"I didn't apply for the housing scheme initiated by our PM because for that scheme I had to pay 5000 monthly that I couldn't afford. And secondly, I wasn't sure whether I'll get anything out of it or not."

"Dirt and garbage are the reasons we will leave this place if the government provides us with a new place. Our space is also less as we cannot accommodate guests at our place."

Subsequently, a few residents were living within Christian community slums. Thus, they had a different answer for moving to another place.

"Yes, we will shift, we want to live in Muslim slums, what else can we want. We heard that the political party Xyz will build houses. We gave votes to party Xyz but all Christians gave to party aaa. We have spent our lives but now we want a better 
future for our kids. The Christians here are good. Our kids want to play outside but we cannot let them play outside. The environment is not good here."

"My father came here alone when he came here 40 years ago and decided not to bring his family from the village. This place was enough for him when he brought us here. Now we have less space, our families got large. We are not getting enough money and we plan to sell this house but the money is not enough."

Therefore, this means that addressing the needs of the slum dwellers is very necessary. Income alone cannot improve the conditions of these people. Other factors like clean streets, a good environment, adequate facilities, and enough living space need to be provided to the slum dwellers.

\section{Discussion}

The results showed that the reasons for being stuck in the slums are different across the religious divide. According to the literature, people tend to be stuck in slums due to their existing social networks which act as an agent to keep them in one place (Archer, 2009). As for Christian residents, social capital is the main factor for keeping them to stay in the slums. These people do not want to leave even if the government provides them with housing. This indicates how strong the networks are which supports them and help them survive in the hostile city life. Engstrom et al. (2017) have suggested that relocation is not the best option and it may not be a sensible policy. Similarly, these people want to stay together and do not want to move out of the slums. The Christian residents of the slums are stuck because of a different set of reasons. The major reason for the Christian residents not to move out of the slum is their social capital. These residents, having lived together in the slum for an extended period of time, have developed friendships and kinship bonds with their neighbours. These developed bonds are the bonding and cognitive social capital of these residents, which makes a move to a different location difficult. In the context of Pakistan, where Christians form a minority group, living at this location does also mean that they are among their co-religious community. Nevertheless, if they move to a separate location, the new location may not be such a co-religious community which would harm their communitarian interests. The second reason for the Christians not to move out of the slums is that these slums are located at the center of the city and thus their jobs, hospitals, and the schools of their kids are in the vicinity. Therefore, moving from here to another location would be troublesome for these residents. 
On the other hand, most of the Muslim residents want to leave the slum. The major reason for their inability to leave the slum is poverty. Thus, these slum dwellers, because of poverty, are unable to afford buying a residential property in Islamabad. This forces them to live in the deplorable conditions of the slums. For many of them, if they are given a reasonable opportunity to move to a better location, they will be more than willing to move. The second reason for some of the Muslim residents is what we call "place attachment". These people have gotten used to living in that location and thus have gotten attached to it, making the move a difficult task. The attachment that these residents report can be categorized into two categories. The first category is that of those people who are "habitually attached" to their place of living. These are the people who have been living here for an extended period. As a result, they have become so attached to the place that they do not want to move to another location even if it is a far better one. This is the place they call "home". The second category is those who are "conditionally attached" to their place of living. These residents are in a certain "condition" that they think that moving to another location would be troublesome or disadvantageous. The condition can be because they have their job in the vicinity of their present accommodation or because the school of their kids is in the vicinity of their present accommodation. Thus, these conditionally attached residents of the slums, due to their present conditions, is of the view that moving is not in their best interest.

The novelty of this paper lies in bringing fore results that show that the reasons slum dwellers are stuck in slums differ based on their religion. Even among the same religious groups, different reasons make people stay in slums. While for most of the Muslim residents, it merely provides a location for cheaper accommodation as reported elsewhere in the literature, for the Christian residents the slums perform a form of functional role because they have formed bonding social capital with the rest of the neighbouring residents. This result is in accordance with Ho's theory (Ho, 2014) which states that slums persist because they perform a certain function. Therefore, the Christian residents consider the slums to be a credible location because they are living in a community of their own. This is the first study conducted in Pakistan to reach such a conclusion based on our knowledge.

\section{Conclusion}

This paper has shown different reasons why people from different religious groups are stuck in the slums. The study demonstrates that while Muslim residents want to leave the slums but are stuck due to poverty, Christian residents do not want to leave. The behaviour of Christians can be explained by the credible proposition of Ho. Since Christians find the environment of the slums to be credible, slums perform a certain form of 
functional role. The findings, therefore, show that different religious groups have different reasons for being "stuck" in the slums. Thus, this brings the idea that the slums are not homogenous settlements but is rather a heterogeneous construct. Moreover, the experience of the Christian dwellers shows that slums are not necessarily a location of misery and suffering. Hence, they can rather be a place of security and credibility for some of the residents as well.

Heterogeneity of the slums is an important area of study that has long been overlooked in the literature as most of the literature tends to treat slums as homogenous constructs. This paper brings forth two important ideas. The first idea is that the slums are heterogeneous constructs and the second idea is that the slums are living organisms that provide safety, security, and a sense of belonging to some of the residents. The second idea is that relocation of slum dwellers may be of importance for the policymakers and they may deem it necessary from a certain point of view. However, policymaker must also understand that the reason all slum dwellers lives in the slum is not the same and that some may not want to relocate. This reason must, therefore, be kept in consideration when the policies are being drafted. A lack of such understanding would lead to the failure of the policies.

\section{References:}

1. Adabre, M. A., \& Chan, A. P. C. (2014). Critical success factors (CSFs) for sustainable affordable housing. Building and Environment.

2. Addo, I. A. (2014). URBAN LOW INCOME HOUSING DEVELOPMENT IN GHANA: POLITICS, POLICY AND CHALLENGES. In Mi. P.Amado (Ed.), Urban Planning: Practices, Challenges and Benefits. Nova publishers.

3. Agarwal, S., \& Taneja, S. (2005). All Slums are Not Equal: Child Health Conditions Among the Urban Poor. INDIAN PEDIATRICS, 42.

4. Amirthalingam, K., \& Lakshman, R. W. D. (2009). Displaced livelihoods in Sri Lanka: An economic analysis. Journal of Refugee Studies, 22(4), 502-524. https://doi.org/10.1093/jrs/fep031

5. Archer, D. (2009). SOCIAL CAPITAL AND PARTICIPATORY SLUM UPGRADING IN BANGKOK, THAILAND. UNIVERSITY OF CAMBRIDGE.

6. Auyero, J. (1999). 'This is a lot like the Bronx, isn't it?' Lived experiences of marginality in an Argentine slum. International Journal of Urban and Regional Research, 23(1), 45-69. https://doi.org/10.1111/1468-2427.00178

7. Avery, D. R., McKay, P. F., \& Wilson, D. C. (2008). What Are the Odds? How Demographic Similarity Affects the Prevalence of Perceived Employment Discrimination. Journal of Applied Psychology. https://doi.org/10.1037/0021-9010.93.2.235 
8. Bah, E. M., Faye, I., \& F.Geh, Z. (2018). Slum Upgrading and Housing Alternatives for the Poor. In Housing Market Dynamics in Africa. Palgrave Macmillan, London. https://doi.org/https://doi.org/10.1057/978-1-137-59792-2_6

9. Baker, J. L. (2007). Bangladesh Dhaka: Improving Living Conditions for the Urban Poor.

10. Becker, G. S. (1965). A Theory of the Allocation of Time. The Economic Journal, 75, 493-517.

11. Bird, J., Montebruno, P., \& Regan, T. (2018). Life in a slum: understanding living conditions in Nairobi's slums across time and space. 33(3), 496-520. https://doi.org/10.1093/oxrep/grx036

12. Bourdieu, P. (2018). The forms of capital. In The Sociology of Economic Life, Third Edition (pp. 78-92). https://doi.org/10.4324/9780429494338

13. Brueckner, J. K., \& Lall, S. V. (2014). Cities in Developing Countries: Fueled by Rural-Urban Migration, Lacking in Tenure Security, and Short of Affordable Housing. In G. Duranton, J. V. Henderson, \& W. Strange (Eds.), Handbook of Regional and Urban Economics, .

14. Cameron, S. (2009). Education in slums of Dhaka, Bangladesh. 10th UKFIET International Conference on Education and Development.

15. Capital Development Autority - Planning Wing (2019). Information of the general public for awarness. Capital development authority.

16. Cerezo, C. E. V. (2003). The case of Guatemala City, Guatemala.

17. Chimhowu, A., \& Hulme, D. (2006). Livelihood dynamics in planned and spontaneous resettlement in Zimbabwe: Converging and vulnerable. World Development, 34(4), 728-750. https://doi.org/10.1016/j.worlddev.2005.08.011

18. Chug, S. (n.d.). Drop out in secondary education A study of children living in slums of Delhi.

19. Cohen, S. (2004). Social relationships and health. In American Psychologist (Vol. 59, Issue 8, pp. 676-684). https://doi.org/10.1037/0003-066X.59.8.676

20. Coleman, J. S. (1990). Foundations of Social Theory (Norms. In Contemporary Sociology (Vol. 19, Issue 6). https://doi.org/10.2307/2073169

21. Cook, K. S. (2005). Networks, Norms, and Trust: The Social Psychology of Social Capital* 2004 Cooley Mead Award Address. Social Psychology Quarterly, 1.

22. Davis, M. (2004). Planet of Slums: Urban Involution and the Informal Proletariat. New Left Review. https://doi.org/10.1215/0961754X-2008032 
23. El-Shorbagy, D. A., \& El-Shafie, D. M. (2014). AN ASSESSMENT STUDY OF UNPLANNED SETTLEMENTS CASE STUDY: ALRUWAIS DISTRICT, JEDDAH, SAUDI ARABIA. European Scientific Journal, 10(32).

24. Engstrom, R., Pavelesku, D., \& Tanaka, T. (2019). Mapping Poverty and Slums Using Multiple Methodologies in Accra, Ghana. Joint Urban Remote Sensing Event (JURSE).

25. Engstrom, R., Pavelesku, D., Tanaka, T., \& Wambile, A. (2017). Monetary and non-monetary poverty in urban slums in Accra: Combining geospatial data and machine learning to study urban poverty. http://www.cirje.e.utokyo.ac.jp/research/workshops/emf/paper2017/emf0724_2.pdf

26. Engstrom, R., Sandborn, A., Yu, Q., \& Burgdorfer, J. (2015). Mapping Slums Using Spatial Features in Accra, Ghana. Joint Urban Remote Sensing Event.

27. Ferranti, D. De, Perry, G. E., G, F. H., Ferreira, \& Walton, M. (2004). Inequality in Latin America. Washington DC: World Bank.

28. Gandhi, S. (2012). Economics of Affordable Housing in Indian Cities The Case of Mumbai. Environment and Urbanization ASIA, 221-235.

29. Geary, J., \& Graff, J. (2005, November). Restless Youth. TIME.

30. Gittell, R., \& Vidal, A. (1998). Community Organizing: Building Social Capital as a Development Strategy. American Sociological Association.

31. Glaeser, E. L. (2014). A WORLD OF CITIES: THE CAUSES AND CONSEQUENCES OF URBANIZATION IN POORER COUNTRIES. Journal of the European Economic Association, 12(5), 1154-1199.

32. Government of Pakistan (2018). National assembly secretariat Questions for oral answers and their replies.

33. Gulyani, S., \& Bassett, E. M. (2010). The Living Conditions Diamond: An Analytical and Theoretical Framework for Understanding Slums. Environment and Planning A: Economy and Space, 42(9), 2201-2219. https://doi.org/10.1068/a42520

34. Hasan, A., \& Mohib, M. (2003). REPORTING ON 'SLUMS' IN SELECTED CITIES.

35. Ho, P. (2014). The "Credibility Thesis" and its Application to Property Rights: (In)Secure Land Tenure and Social Welfare in China. Land Use Policy, 40.

36. Hossain, S. (2007). Poverty and vulnerability in urban Bangladesh: the case of slum communities in Dhaka City. International Journal of Development Issues, 6(1), 50-62. 
37. Hummon, D. M. (1992). Community attachment: Local sentiment and sense of place. Plenum Press.

38. J.Stokes, C. (1962). A Theory of Slums. Land Economics, 3.

39. Kain, J. F. (1968). Housing Segregation, Negro Employment, and Metropolitan Decentralization. The Quarterly Journal of Economics. https://doi.org/10.2307/1885893

40. Larsen, L., Harlan, S. L., Bolin, B., Hackett, E. J., Hope, D., Kirby, A., Nelson, A., Rex, T. R., \& Wolf, S. (2004). Bonding and bridging: Understanding the relationship between social capital and civic action. Journal of Planning Education and Research, 24(1), 64-77. https://doi.org/10.1177/0739456X04267181

41. Lee, S., Chung, J. E., \& Park, N. (2018). Network Environments and Well-Being: An Examination of Personal Network Structure, Social Capital, and Perceived Social Support. Health Communication, 33(1), 22-31. https://doi.org/10.1080/10410236.2016.1242032

42. Lin, N. (2001). Social capital. A theory of social structure and action. Cambridge University Press.

43. Low, S. M. (1992). Symbolic Ties That Bind. In Place Attachment (pp. 165-185). Springer US. https://doi.org/10.1007/978-1-4684-8753-4_8

44. Lucci, P., Bhatkal, T., \& Khan, A. (2017). Are we underestimating urban poverty? World Development.

45. Lucci, P., Bhatkal, T., Khan, A., \& Berliner, T. (2015). What works in improving the living conditions of slum dwellers A review of the evidence across four programmes.

46. Maguire, M., \& Delahunt, B. (2017). Doing a Thematic Analysis: A Practical, Step-by-Step Guide for Learning and Teaching Scholars. AISHE-J.

47. Marx, B., Stoker, T., \& Suri, T. (2013). The Economics of Slums in the Developing World. Journal of Economic Perspectives, 27(4), 187210.

48. Menon, A. (2013). Barriers to Parental Involvement in Early Childhood Education Classrooms in Mumbai Slums as Perceived by Parents. Literacy Information and Computer Education Journal (LICEJ), 2(2).

49. Murrugarra, E., \& Valdivia, M. (1999). The returns to health for peruvian urban adults: differentials across genders, the life cycle and the wage distribution.

50. Nath, S. R. (2009). Educational Marginalization in Bangladesh.

51. Newman, A., Nielsen, I., Smyth, R., \& Hirst, G. (2018). Mediating Role of Psychological Capital in the Relationship between Social Support and Wellbeing of Refugees. International Migration, 56(2), 117-132. https://doi.org/10.1111/imig. 12415 
52. Nowell, L. S., Norris1, J. M., White1, D. E., \& Moules, N. J. (2017). Thematic Analysis: Striving to Meet the Trustworthiness Criteria. International Journal of Qualitative Methods, 16.

53. Oakley, A. (1998). Gender, methodology and people's ways of knowing: Some problems with feminism and the paradigm debate in social science.

Sociology. https://doi.org/10.1177/0038038598032004005

54. Omole, K. F. (2010). An Assessment of Housing Condition and SocioEconomic Life Styles of Slum Dwellers in Akure, Nigeria. Contemporary Management Research, 6(4), 273-290.

55. Osmani, M., \& Ergen, M. (2019). Expected Versus Real Effects and Challenges of Urbanization in Albania During the Transition: A Focus Group-Based Assessment. European Scientific Journal ESJ, 15(25). https://doi.org/10.19044/esj.2019.v15n25p79

56. Östergren, O. (2018). Educational inequalities in mortality are larger at low levels of income: A register-based study on premature mortality among 2.3 million Swedes, 2006-2009. Elsevier, 5, 122-128.

57. Pager, D., \& Shepherd, H. (2008). The Sociology of Discrimination: Racial Discrimination in Employment, Housing, Credit, and Consumer Markets. Annual Review of Sociology. https://doi.org/10.1146/annurev.soc.33.040406.131740

58. Pakistan Bureau of Statistics (2017). Provisional summary results of 6th population and housing census-2017. www.pbs.gov.pk

59. Pero, V., Cardoso, A., \& Elias, P. (2003). Urban Regeneration and Spatial Discrimination: the Case of Favelas Residents in Rio. Proceedings of the 31th Meeting of the Brazilian Association of Graduate Programs in Economics, Belo Horizonte.

60. Portes, A. (1998). Social Capital: Its Origins and Applications in Modern Sociology. In Annual Review of Sociology (Vol. 24, Issue 1, pp. 1-24). https://doi.org/10.1146/annurev.soc.24.1.1

61. Pretty, G. H., Chipuer, H. M., \& Bramston, P. (2003). Sense of place amongst adolescents and adults in two rural Australian towns: The discriminating features of place attachment, sense of community and place dependence in relation to place identity. Journal of Environmental Psychology, 23(3), 273-287. https://doi.org/10.1016/S0272-4944(02)00079-8

62. Rashid, S. F. (2009). Strategies to Reduce Exclusion among Populations Living in Urban Slum Settlements in Bangladesh. Journal of Health Population and Nutrition.

63. Robert, P. (1999). Bowling Alone. The Collapse and revival of American Community. In Bowling Alone:The Collapse and Revival of 
American

Community

(pp.

$15-28)$. https://doi.org/10.1109/ISWCS.2004.1407284

64. Salon, D., \& Gulyani, S. (2010). Mobility, Poverty, and Gender: Travel "Choices" of Slum Residents in Nairobi, Kenya. Transport Reviews.

65. Sanderson, D. (2012). Building livelihoods to reduce risk among the most marginalized in urban areas: Strategic approaches from Dhaka. Environmental Hazards, 11(2), 112-122. https://doi.org/10.1080/17477891.2011.609881

66. Sartori, J., Caiaffa, P. W., Capon, P. A., Lilford, P. R. J., Population, A., Cl, M., Africa, S., Branch, C. D., Human, N., Programme, S., Wing, S., \& Lilford, R. J. (n.d.). The history, geography and sociology of slums and the health problems of people who live in slums. 44(0).

67. Shah, A. (2016). Determinants of Slums in Islamabad A Philosophical Approach. Pakistan Journal of Urban Affairs, 1(5).

68. Shams, S., C., M. M. S., \& Ahsan, A. (2014). Housing problems for the Middle and Low income people in Bangladesh: Challenges of Dhaka Megacity. Environment and Urbanization Asia.

69. Steel, P., Taras, V., Uggerslev, K., \& Bosco, F. (2018). The Happy Culture: A Theoretical, Meta-Analytic, and Empirical Review of the Relationship Between Culture and Wealth and Subjective Well-Being. Personality and Social Psychology Review, 22(2), 128-169. https://doi.org/10.1177/1088868317721372

70. Sultana, I. (2019). Social Factors Causing Low Motivation for Primary Education among Girls in the Slums of Karachi. Bulletin of Education and Research, 41(3), 61-72.

71. Sweet, D., Byng, R., Webber, M., Enki, D. G., Porter, I., Larsen, J., Huxley, P., \& Pinfold, V. (2018). Personal well-being networks, social capital and severe mental illness: Exploratory study. British Journal of Psychiatry, 212(5),

308-317. https://doi.org/10.1192/bjp.bp.117.203950

72. Tran, T. A. (2015). The role of social capital and community ties in rebuilding livelihoods of displaced households in peri-urban areas of Ho Chi Minh City.

73. Turok, I., \& Borel-Saladin, J. (2016). The theory and reality of urban slums: Pathways-out-of-poverty or cul-de-sacs? Urban Studies Journal Limited.

74. Zulu, E. M., Beguy, D., Ezeh, A. C., Bocquier, P., Madise, N. J., Cleland, J., \& Falkingham, J. (2011). Overview of migration, poverty and health dynamics in Nairobi City's slum settlements. Journal of Urban Health, 88(S2), 185-199. https://doi.org/10.1007/s11524-0119595-0 